\title{
INNOVATION POTENTIAL: IMPACT ON THE NATIONAL ECONOMY'S COMPETITIVENESS OF THE EU DEVELOPED COUNTRIES
}

\author{
Iryna Lomachynska ${ }^{1}$ \\ Odessa I.I. Mechnikov National University, Ukraine \\ Ivelyna Podgorna ${ }^{2}$ \\ Institute for Market Problems and Economic and Ecological Research of the \\ National Academy of Sciences of Ukraine, Ukraine
}

\begin{abstract}
The success of the economy of each country is determined by its innovation development. The purpose of the paper is to investigate the essence of innovation potential and its role in providing the national economy's competitiveness under the conditions of technological changes on the example of the European Union developed countries. The subject of research is the innovation potential of Austria and Germany. Methodology. The study is based on a comparative analysis of approaches to determination and evaluation of innovation potential in specialized economic literature. Analysis and synthesis and the system approach were used to outline the entity of innovation potential, to explore and structure its elements in the context of providing the national economy's competitiveness. The quality and quantity analysis were used to discover general characteristics of the EU countries' innovation development, special aspects of the national innovation systems of Austria and Germany, the role of innovation potential in the national economies competitiveness of these countries. The method of mathematical modelling in economics, in particular, regression analysis based on annual data for the period from 1995 to 2015, was applied to assess the impact of innovation potential on the Austria and Germany competitiveness. The absolute value of GDP and the share of export of goods and services in GDP are used as a dependent variable. Elements that characterize the country's innovation potential were used as independent variables: the share of researchers in R\&D of total population, the share of labour force with advanced education of total working-age population with advanced education, expenditure on tertiary education as a percentage of GDP, R\&D expenditure as a percentage of GDP, patent applications as a percentage of total population. Results of the survey of theoretical works showed that the most multifaceted and comprehensive approach to determining the essence and elements of innovation potential is the "Resources-Results" approach. This very approach was used for empirical analysis of Austria and Germany's innovation potential and evaluation of its impact on the national economic competitiveness of these countries. It has been found that the greatest impact on the development of Germany's national economy is provided by: scientific resources, financial and economic resources, human resources. The most important elements of Austria's innovation potential are financial and economic resources, scientific resources, human resources, as well as the effectiveness of innovation. Generally, the results of the empirical study show a significant contribution of innovation potential to the national economy's competitiveness of the EU developed countries. It was revealed that a pivotal role in the implementation of innovation potential belonged to the state and its efficient innovation policy. Practical implications. Elements of innovation potential (that has a positive effect upon Austria and Germany's economic development) indicate differences in the general characteristics and efficiency of national innovation policy. This allows us to determine and ground the main directions of innovation policy to increase innovation potential efficiency. It was revealed that Austria should adjust its education policy: education system should be more oriented towards the R\&D development and its implementation in the economy. Germany should improve an efficiency of innovation policy (especially in export-oriented industries) and the effectiveness of implementing the R\&D results in the

\footnotetext{
Corresponding author:

${ }^{1}$ Department of Economic Theory and the History of Economic Thought, Odessa I.I. Mechnikov National University.

E-mail: i.lomachynska@onu.edu.ua

${ }^{2}$ Department of Interregional Economic Development of the Ukrainian Black Sea Region, Institute for Market Problems and Economic and Ecological Research of the National Academy of Sciences of Ukraine.

E-mail: ivelina.od@gmail.com
} 
economy, optimize education and employment policies. Value/originality. The obtained results can be used for further developing and improving the investment policy of Germany and Austria. Further research of separate resources and elements of innovation potential will allow expanding the opportunities for the national economy competitiveness increasing that is important in the context of tougher international competition.

Key words: innovation potential, technology, competitiveness, innovation policy, innovation-led growth, innovation potential elements, EU, Austria, Germany.

JEL Classification: $\mathrm{C} 50,032,033$

\section{Introduction}

Innovation is the basis and the driving force of economic growth and the determinant of the national economy's competitiveness. The external economic priorities of countries are changing under the current conditions of globalization, informatisation, and transformation of world processes. Today, one of these priorities is the transnationalization of the world economy through the development of foreign economic activity through the expansion and deepening of bilateral trade and economic relations between countries. In this context, innovation-based competitiveness is becoming a key factor in the success of the countries' economic development. With the growth of global uncertainty, sustainable development can take place only when it relies on a competitive economy, the researchers note (Heiets, Danylenko, Zhulynskyi, Levenets, Libanova, \& Onyshchenko, 2010).

According to scientists, modern economic growth is characterized by the defining importance of scientific and technological progress and the intellectualization of the main economic resources. The innovation component of GDP growth of developed countries increased from 1980 to the beginning of the 21 st century: from $31.0 \%$ to $34.6 \%$ in the US, from $30.6 \%$ to $42.3 \%$ in Japan, from $45.5 \%$ to $50.0 \%$ in Europe (Heiets, et al., 2010).

A great number of international organizations research deals with the study of innovation potential. The development of this problem is actively carried out by the World Bank, the US National Science Foundation, the World Economic Forum (WEF), the Organization for Economic Cooperation and Development (OECD), the Maastricht Economic Research Institute on Innovation and Technology (MERIT, the Netherlands), and the Commission of the European Communities (CES).

European countries take 15 of 25 first places in the Global Innovation Index ranking (Cornell INSEAD WIPO, 2017): Germany - 9th; Austria - 20th. All this allows us to assume that innovations always have played an important role as the basis of the national economies' competitiveness of Austria and Germany.

The purpose of the paper is to investigate the essence of innovation potential and its role in providing the national economy's competitiveness under the technological changes on the example of the European
Union developed countries. To achieve this goal, it is necessary to solve the following tasks: to determine the essence of innovation potential in the "ResourcesResults" approach, to discover and structure its elements for the evaluation of innovation and scientific and technical potential, and to assess their role for competitiveness of the national economies of Austria and Germany.

To solve these problems, the main approaches to the definition of innovation potential were considered in the specialized economic literature, its essence in the context of providing the national economy's competitiveness was justified on the basis of analysis and synthesis methods; innovation potential elements were systematized using the method of comparative and system analysis. Based on the qualitative and quantitative analysis, the special aspects of the EU developed countries innovation policy and Austria and Germany national innovation systems were determined. Further, the influence of innovation potential elements on the competitiveness of Austria and Germany was evaluated on the basis of mathematical modelling in economics, in particular, regression analysis using annual data for the period from 1995 to 2015 .

\section{Theoretical background of the research}

During the last decade, a large number of scientific and practical works was devoted to the study of an innovation development, especially within the context of the national economy's development. Various aspects of this problem are covered in the works of such authors as P. Drucker, L. Fedulova, C. Freeman, A. Galchynskyi, M. Gaman, V. Heiets, Z. Kalcsú, D. Magyar, C. Nauwelaers, F. Porter, A. Reid, V. Semynozhenko.

In the context of the current economic development, the category "innovation potential" deserves a special attention. The concept "innovation potential" was first introduced by C. Freeman in the 1970s-1980s. He believed that innovation was a system of measures to develop, exploit, and deplete the economic, social, and institutional capacity of key innovations. The practical aspect of the "innovation potential" concept is reflected in the works of P. Drucker, where he studies the sources of modern industry development (Drucker, 2009). 
The survey of studies (Nauwelaers \& Reid, 1995; Kalcsú \& Magyar, 2009) allows us to generalize that the innovation potential means the ability to create, implement, and master both own and acquired innovations. Thus, in general terms, innovation potential can be defined as a set of resources, processes, and conditions that are necessary and sufficient for the implementation of innovation activity to achieve the goals of innovation and technological development.

In the economic literature, there are no unified methodological approaches to innovation potential evaluation, distinguishing the structure elements and determining its factors. Some authors explain it as a set of innovation resources (financial, material, intellectual, scientific and technical) that provide an opportunity for innovation activity and creation of innovation technology, products, services - it should be considered as a resource approach to the innovation potential definition Others examine the innovation potential from the standpoint of the result of innovation: the real product obtained in the innovation process. In this case, the innovation potential is presented as possible, produced in the future, innovative products (Kornilov \& Beliaev, 2012).

We are of the opinion that innovation potential should be considered from two sides: the innovation process and the result of this process. Thus, the combination of resource-based and results-based approaches deserves the greatest attention. The key indicators for assessing innovation potential in the framework of the resourceefficient approach are presented in Figure 1.
An identical methodological approach to the evaluation of innovation development is used to determine the Global Innovation Index (GII). GII is an indicator of the country's innovation and technological development: the efficient use of resources. It is calculated by the method of the International business school INSEAD in conjunction with Cornell University and the World Intellectual Property Organization (WIPO) and represents the most comprehensive set of indicators of innovation development in various countries of the world. The index is calculated as the average of two sub-indices: available resources and conditions for innovation (Innovation Input) and practical results (Innovation Output). Thus, the final index is a cost-effectiveness ratio, which allows an objective assessment of the effectiveness of efforts to develop innovations in a particular country (Cornell INSEAD WIPO, 2017).

European countries show high results in the GII world ranking. In the GII 2017 report, European countries take 15 of 25 first places in the world ranking. Europe is strong in human capital, scientific researches, infrastructure and business development level. European countries are almost leading half the indicators in composing the GII, including the highly skilled specialists' share in general employment, university and industry cooperation, patent applications and scientific and technical articles and the quality of scientific papers (The World Intellectual Property Organization, 2017).

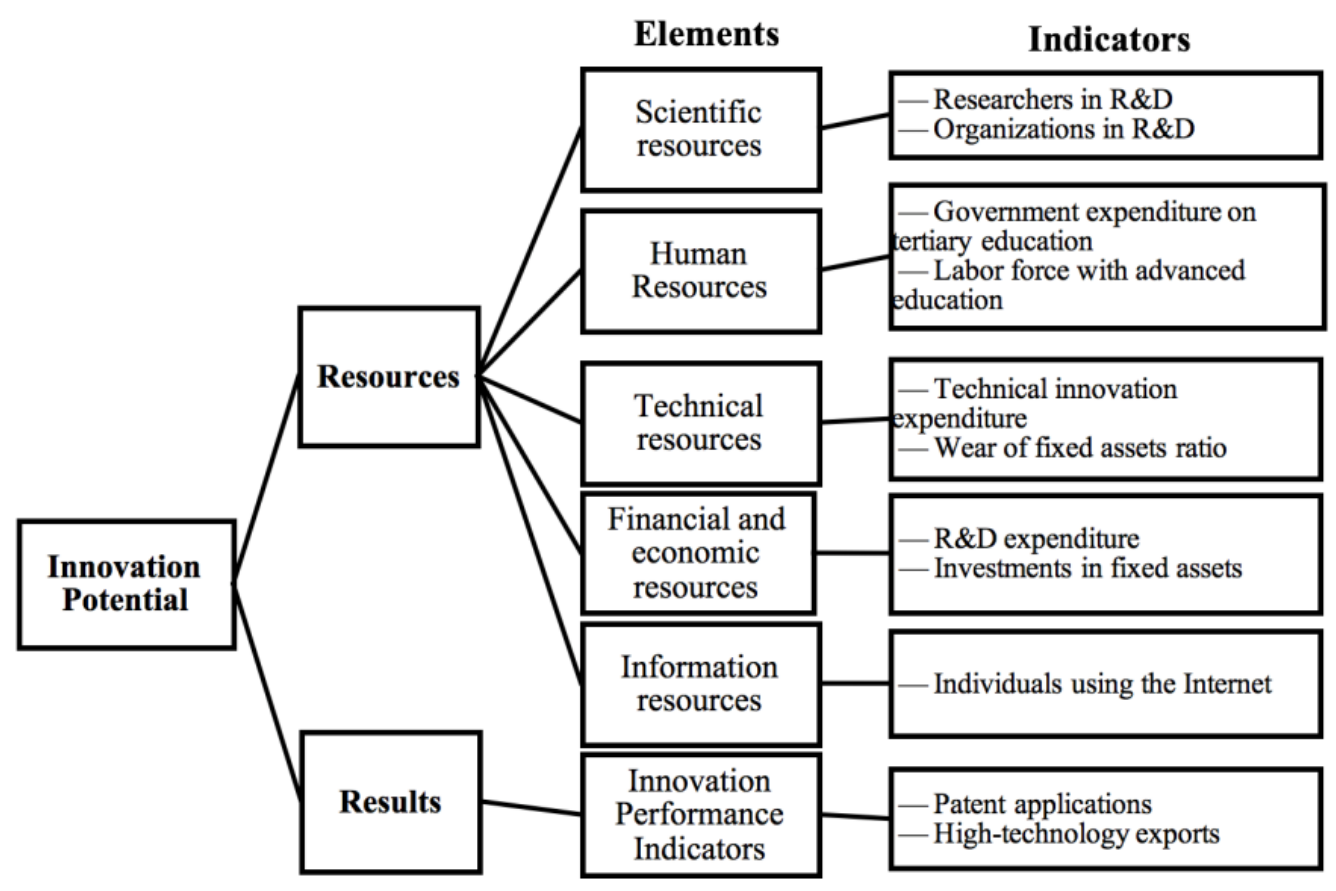

Fig. 1. Innovation potential in the "Resources-Results" concept

Source: developed by the authors 


\section{Innovation development in the European Union countries}

Innovation is vital for European competitiveness in the global economy. The EU is implementing policies and programmes to support the innovation development to increase investment in $\mathrm{R} \& \mathrm{D}$. The EU Commission is developing policies that support innovative development in priority areas and SME and helps to accelerate the broad commercialization of innovations, mainly through the program "Horizon 2020” (The European Commission, 2017).

Small and medium-sized enterprises (SMEs) are a priority area in EU innovation policy. The smaller the company, the more it encounters restrictions on innovation or the commercialization of the innovations. According to the European Commission (2017), about $63 \%$ of companies with from one to nine employees having introduced at least one innovation since 2011 , compared to $85 \%$ of companies of 500 or more workers. However, an important challenge for SMEs remains the lack of financial resources to commercialize innovation.

Innovation takes on enormous importance in crisis periods. The success of national innovation policy depends on the government's ability to foresee and actively promote the innovations during the depression and recovery periods (Akaev, 2010). Overcoming structural crises requires the introduction of innovations at the centre of any governments' decision-making process, while "innovation policy must become growth policy and vice versa” (Mazzucato \& Perez, 2014). At the same time, innovation policy should influence: financial market, labour market and especially taxation (Mazzucato \& Perez, 2014).

Research and Development Expenditure (R\&D) is the main indicator of public and private sector activities targeted at getting competitive advantages in science and technology. The 20-years statistics of EU countries R\&D expenditure dynamic (Fig. 2) demonstrates the following. During the 1996-2007 R\&D expenditure

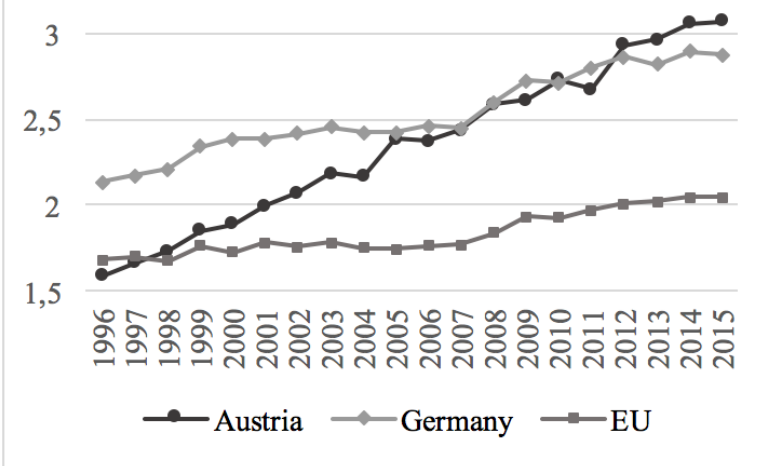

Fig. 2. Research and development expenditure (\% of GDP)

Source: developed by the authors, taking into account (UNESCO, 2017; the World Bank, 2017) were stable at $1.6-1.7 \%$. Since 2008, the level of EU countries R\&D expenditure skyrocketed from $1.77 \%$ in 2007 to $1.93 \%$ in 2009 . The positive trend continued in the following years, and the indicator exceeded $2 \%$ in 2012. Such dynamics show that the EU pays due attention to innovation development. That is especially important during the fundamental technological changes that are currently going on.

The example of the European Union developed countries, which achieved a significant result in the construction of an innovation-oriented economy, shows that balanced government innovation policy provides sustainable economic development. Thus, government support for innovation sector is extremely important because of the risks that inevitably arise in the process of innovation.

For a more in-depth research of the innovation potential and its impact on the national economy of individual countries, in particular, their competitiveness, further we will consider this problem on the example Australia and Germany.

\section{Innovation potential of Austria}

Austria ranked 15th in the world in terms of GDP per capita (the World Bank, 2017). Despite the fact that the Austrian contribution to the world GDP is about $0.5 \%$, Austria took the 20th place in the Global Innovation Index ranking 2016 (The World Intellectual Property Organization, 2017). According to the European Patent Office (2017), Austria ranks 14th in the world ranking by the number of patents registered for the first time and 7th by the patent applications for 1 million citizens. In 2015, the number of patents increased from 1964 to 1992. Leaders were power engineering, special machinery, transport, medical technologies, measurement and control instruments. The Austrian innovation-based economy determines national high competitiveness. According to the Global Competitiveness Index, Austria ranked 18th in 2017 (the World Economic Forum, 2017) rising to one position.

Austrian innovation policy analysis shows that the measures designed to create new mechanisms for organizing interaction between the industrial and scientific sectors at different levels are constantly being undertaken in the country. There are great numbers of different business forms, research and industrial centres. Clusters and competence centres are the largest of them. A network of clusters was established in 2008 on the Ministry of Science, Research and Economics Initiative, in cooperation with the federal states. These clusters unite enterprises, technological parks, and scientific centres to support business and science cooperation under the Industry 4.0, as well as to increase the SMEs competitiveness (Trade Representation of the Russian Federation in the Austrian Republic, 2017). 
The basis for the Austrian high-tech economy sector success is active R\&D and focus on the implementation of their results. Leading innovation companies are supported at the state level through the Austrian Research Support Agency (FFG). It is the national Austrian agency for financing industrial R\&D. The FFG estimates that around 420-450 million Euros are annually allocated as grants to stimulate innovation R\&D (Trade Representation of the Russian Federation in the Austrian Republic, 2017). FFG classifies Austria as one of the 3 leading European sites for research in the field of ICT. In particular, $15-20 \%$ of all Austrian $\mathrm{R} \& \mathrm{D}$ in ICT is channeled into the development of microcircuits. The successful development of ICT companies in Austria is facilitated by the participation in the EU framework programs (Österreichische Forschungsförderungsgesellschaft, 2017).

The Austrian innovation system and its prospects are the subject of constant discussions in political and scientific circles. According to independent assessments, Austria does not belong to the so-called Innovation Leaders, it tops the list of so-called Innovation followers - countries whose innovation level is at the level is the average European and higher (The European Commission, 2012).

Summarizing the innovation potential of Austria, one can single out a high level of spending on R\&D (3.07\% of GDP in 2016) (the World Bank, 2017). The share of $\mathrm{R} \& \mathrm{D}$ expenditure in Austria is at the level of 3.07-3.10\% of GDP for the third consecutive year, according to EU targets 2020. According to this indicator, Austria is on the third place in the EU after Finland and Sweden, and above Germany with a rate of $2.88 \%$ since 2012 (the World Bank, 2017). Overall private sector financing reached 64 percent (UNESCO, 2017), which almost corresponds to the optimal ratio of state-business investments, according to European experts: $1 / 3$ to $2 / 3$. At the same time, it is worth noting some potential human resources problems: the share of graduates with higher and higher technical education in Austria is almost twice lower than in Europe (the World Bank, 2017).

Austria has consistently ranked at a high average among EU innovation ratings: on 8-11th place among 28 EU countries (Trade Representation of the Russian Federation in the Austrian Republic, 2017). There are still several deterrents to improve these ratings: human resources problems, as well as a significant backlog in the development of venture capital financing - in recent years, this indicator as a percentage of Austria's GDP has decreased by 8 percent, while the EU average has grown by 10 percent (Trade Representation of the Russian Federation in the Austrian Republic, 2017).

Experts believe that an increase of industrial companies innovation potential is possible through comprehensive measures, including: formation of scientific priorities, development of principles for supporting the scientific and industrial sector, personnel training, simplification of research and innovation activity management, sustainable and increasing funding for R\&D (Trade Representation of the Russian Federation in the Austrian Republic, 2017). The analysis of the Austrian government's measures in support of $\mathrm{R} \& \mathrm{D}$ shows that there were a number of steps in this direction during the recent years.

\section{Innovation potential of Germany}

The German economy is the largest, most stable and competitive economy in Europe. Germany took the 2nd place in the world in Global Competitiveness Index for 2017-2018 (the World Economic Forum, 2017). Over the past 10 years, Germany has entered the world's leading positions in research and innovation spheres, despite the crisis.

Today, German innovations have the highest demand in the world. The country ranks first in the world in some innovation products research and production, while in others it seeks to reach the leading positions in the near future. Germany confidently ranks first in Europe in innovation products export: exports of hightech products are $16.6 \%$ of total exports in 2016 (the World Bank, 2017).

The country could not provide such a high innovation products level without investment in science and scientific developments. R\&D expenditure to GDP is one of the most important indicators of the national economic development. Germany is very attentive to this indicator, evaluating $\mathrm{R} \& \mathrm{D}$ expenditure as an opportunity to provide constant growth and sustainable economic development to maintain national economy's competitiveness in the world market. In 2015, the total amount of German R\&D expenditure reached 112 billion US dollars (the World Bank, 2017). State financing reached about 19 billion US dollars when Austria has a high degree of dependence on public funding (about $36 \%$ of total expenditure on R\&D) (UNESCO, 2017).

Focusing on the European "Strategy 2020" (it is planned to achieve the indicator of $R \& D$ expenditure at $3 \%$ in the EU countries.), Germany has already exceeded its target and seeks to further increase its spending on science and research. This indicator is planned to increase to $3.5 \%$ by 2020 . Priority R\&D areas are: energy and ecology, healthcare, communications, engineering and transport, security. Key sectors among them are: alternative energy sources, electric car industry, information technology, energy efficiency, health (emphasis on caring for the elderly), healthy eating of the population, etc. (Trade Representation of the Russian Federation in the Federal Republic of Germany, 2017).

The German government notes the need to maintain high $R \& D$ level in the priority field of science and 
technology using both governmental and public support mechanisms, improving the professional scientific training in higher education institutions and paying attention to fundamental research that makes it possible to maintain the German science competitiveness in the world.

The German R\&D management system consists of bodies and departments at the federal and land levels. The Council for Science (Wissenschaftsrat - WR) is one of the main advisory bodies in the field of science that determines the priority areas of scientific research in Germany. The main source of R\&D funding is the $\mathrm{BMBF}$, the body responsible for the general formation of state R\&D policy. The allocation of R\&D funds is based on the principle of public-private partnership. The public funding share is about one-third, two-thirds are provided by industry (Trade Representation of the Federal Republic of Germany, 2017).

Germany national innovation system (NIS) is a complex and diversified system, including government authorities, scientific and educational organizations, high-tech business, primarily SMEs. In total, there are about 750 research organizations in the FRG that receive funds from the state budget. In addition, special centres for research and development have been established, working directly with industrial enterprises. About 460 thousand people are engaged in R\&D, about half of them - scientists and engineers (Trade Representation of the Federal Republic of Germany, 2017).

The development of the innovation-based economy is an effectiveness criterion of public policy according to the policy of the German government. The government claims that only innovation-led growth will provide Germany with global competitiveness. In this regard, the German government is increasing investment, improving education and research quality, promoting the cooperation between universities, research institutions and the industry.

To stimulate innovation processes, a set of measures is being implemented to create favourable conditions for the rapid implementation of $\mathrm{R} \& \mathrm{D}$ results into the industrial sector. German government increased innovation research funding to $3 \%$ of production across the country in 2016, the, with a target of 3.5\% for 2017 (Trade Representation of the Federal Republic of Germany, 2017). The R\&D development should help to reduce costs of national enterprises, as well as increase their competitiveness.

All this makes it possible to evaluate German innovation potential as high one: resource base, conditions for innovation development and implementation, and the practical results achieved in implementing the innovation policy.

The method of mathematical modelling in economics, in particular, regression analysis based on annual data for the period from 1995 to 2015, was used to assess the impact of innovation potential on the Austria and Germany competitiveness. The absolute value of GDP and the share of export of goods and services in GDP are used as a dependent variable. Elements that characterize the country's innovation potential were used as independent variables: the share of researchers in $\mathrm{R} \& \mathrm{D}$ of total population, the share of labour force with advanced education of total working-age population with advanced education, expenditure on tertiary education as a percentage of GDP, R\&D expenditure as a percentage of GDP, the patent applications as a percentage of total population.

\section{Innovation potential as a determinant of competitiveness: empirical research}

The impact of national economy's innovation potential on the competitiveness growth was investigated using mathematical modelling in economics, in particular, regression analysis. Annual data for the period 1995-2015 were used for the research. We used the value of GDP and exports of goods and services as competitiveness indicators. As independent variables, we defined a number of ones characterizing the national innovation potential (Fig. 1): the share of researchers in $\mathrm{R} \& \mathrm{D}$ of total population (X1), the share of labour force with advanced education of total working-age population with advanced education $\left(X_{2}\right)$, expenditure on tertiary education as a percentage of GDP $\left(X_{3}\right)$, $\mathrm{R} \& \mathrm{D}$ expenditure as a percentage of GDP $\left(\mathrm{X}_{4}\right)$, - as a "resource" and the patent applications as a percentage of total population $\left(X_{5}\right)$ - as a "result". Information resources and infrastructure are important elements of the innovation potential having a high level in Austria and Germany. Their role in providing the competitiveness of these countries is beyond doubt. Therefore, we do not include these elements in the model.

We will investigate the impact of the innovation potential on the absolute value of the gross domestic product $\left(Y_{1}\right)$ of Germany and Austria.

Constructing the model for Germany, the variables $X_{2} X_{4} X_{5}$ were excluded from the model as insignificant by step-wise selection of independent and evaluation of their significance. The obtained model has the form:

$$
\mathrm{Y}_{1}=0,662^{*} \mathrm{X}_{1}+0,382^{*} \mathrm{X}_{3}
$$

By analysing the statistical results of the model (1), it was found that the model is significant with 99\% probability by the Fisher criterion. All independent variables are significant with a confidence level of $99 \%$ and affect the dependent variable by the Student's criterion. The R-square and its corrected value are about 0.854 and 0.837 , respectively, that means the statistical quality of the constructed model. Thus, the dynamics of the number of researchers in $\mathrm{R} \& \mathrm{D}$ and government spending on advanced education has a direct impact on Germany's GDP growth.

Germany is an export-oriented country that is its competitive advantage in the EU. The share of high-tech 
export in the total export of goods is $16.7 \%$ (the World Bank, 2017). In this regard, we will evaluate the impact of Germany's innovation potential on exports of goods and services $\left(Y_{2}\right)$.

When constructing the model, the variables $X_{3}$ and $X_{5}$ were excluded from the model as insignificant by stepwise selection of independent and evaluation of their significance. As a result, the following model was obtained:

$$
Y_{2}=1,737^{*} X_{1}-0,538^{*} X_{2}-1,247^{*} X_{4}
$$

The model is statistically qualitative according to the R-square and its corrected values are 0.947 and 0.937 , respectively. Estimating the significance level of the model (2), it can be argued that the model is significant with $99 \%$ probability by the Fisher criterion. All the coefficients are significant with $99 \%$ probability and affect the dependent variable by the Student's test. Based on the results of the model, it can be concluded that the growth of German exports of goods and services depends on the increased number of researchers in R\&D. The share of labour force with higher education among people of working age with advanced education and expenditures on R\&D has a reverse effect on GDP dynamics.

It can be concluded that there are some obvious problems in the human resources' element of the German innovation potential. On the one hand, it is possible to affirm an effective government education policy that has been conducted for many years, as evidenced by direct dependence on GDP. On the other hand, the growth of the labour force with advanced education affects negatively the country's exports that can also be explained by the consequences of the global financial crisis, the EU debt crisis, and the migration situation in the country, which are typical for the research period. It is necessary to note a nonoptimal structure of higher education graduates in terms of innovation development, namely, the shortage of technical majors graduates. Under the current conditions of globalization, the humanitarian, social, and public spheres majors are becoming increasingly popular. Growing immigration leads to an increase in the number of people with higher education, but it can be assumed that their education level does not meet the requirements of the modern technological mode of the German economy.

The results for Germany can also be explained by the fact that high-tech products are mostly sold on the domestic market and are less exported due to a high price competition in international markets. Competition with Asian countries leads to a cost increase of new patents, so the $\mathrm{R} \& \mathrm{D}$ comparative costs are also increasing.

During the regression analysis, there has been revealed an ambiguous interconnection between the economic competitiveness and $\mathrm{R} \& \mathrm{D}$ expenditure and not revealed the interconnection with patent applications. Thus, despite the high efficiency of Germany's innovation policy, its effectiveness is insufficient. This can be explained by the fact that not all R\&D results are fully implemented.

So, Germany should further strengthen its position in the world high-tech products market by searching for new ways to reduce its cost, needs to improve the policy orientated on speeding up the broad and effective implementation of R\&D results in the real sector of the economy.

To analyse the impact of innovation potential on the competitiveness of Austria's national economy, we will construct a regression model using a similar set of independent variables and the volume of GDP as a dependent $\left(Y_{3}\right)$ :

$$
Y_{3}=0,194^{*} X_{1}+0,808^{*} X_{4}+0,232^{*} X_{5}
$$

After the analysis in SPSS, it can be concluded that this variation of factors are largely explained the selected dependent variable, according to the determination coefficient and its corrected value are 0.931 and 0.916 . The evaluation of the model showed that all coefficients are significant and affect the dependent variable by the Student's test, and the dependence is significant with $99 \%$ probability by the Fisher criterion. So, the positive impact on the GDP of Austria is provided by researchers in $R \& D, R \& D$ expenditures, and the patent applications.

The share of high-tech export in the total export of goods and services in Austria is 13.4\% that is lower than in Germany (The World Bank Group, 2017). The impact of innovation potential on the volume of exports of goods and services $\left(Y_{4}\right)$ as an indicator of the Austrian competitiveness will be examined. As a result of regression analysis, the following model was obtained:

$$
\text { Y_4 }=0,798^{*} \mathrm{X} 1-0,667^{*} \mathrm{X} 3+0,519^{*} \mathrm{X} 4
$$

The model evaluation (4) determined the high level of its significance by the Fisher criterion. By the Student's criterion, all independent variables are significant with 95\% confidence level and affect the dependent variable. The R-square and its adjusted value are 0.835 and 0.799 , respectively. As a result, it can be summarized that the researchers in $\mathrm{R} \& \mathrm{D}$ and $\mathrm{R} \& \mathrm{D}$ expenditures have a direct impact on the export of goods and services, as well as GDP. The expenditure on tertiary education and the export of goods and services in Austria are inversely related. There is no correlation between patents and GDP.

So, the results of researching the impact of innovation potential on GDP and the export of goods and services in Austria are almost identical. It can be generalized that, other things being equal, Austria innovation potential in the context of the national economy's competitiveness is used more efficiently than Germany in the period under study. It should be noted that as the scientific, financial, and economic resources of 
the innovation potential, as the results of innovation activity have been identified with the positive effect for Austria's GDP. However, the impact of the human resources of innovation potential on Austria's GDP was not revealed. In this regard, the Austrian government should further integrate the education system with the development and implementation of R\&D in economic activity. Moreover, the model of the dependence of exports and advanced education expenditures revealed an inverse dependence. It can be assumed that this is a consequence of Austria's modern education policy aimed at the growth of graduates with higher technical education the indicator is almost half that the EU average (the World Bank Group, 2017). As a result, there is a large investment in education today, and return on investment is expected in the future.

Such disputable modelling results for both countries can be explained by the fact that the study period is a recession phase of the long economic cycle. Moreover, the indicators used for the mathematical modelling are not completely objective: it is more profitable for multinational companies, which are mainly implementing the newest technologies in mass production, to carry out production in subsidiaries than to produce goods and services in its own countries of origin and then export them.

\section{Conclusion}

Under the modern conditions of technological changes and globalization, it is important to use innovation potential to provide the development of national economy and increase its competitiveness. The most complete and comprehensive approach to the evaluation of innovation potential is the "ResourcesResults" approach. The main elements of the innovation potential are scientific, human, technical, financial and economic, information resources, as well as the effectiveness of innovation (patent applications, the volume of exports of high-tech products, etc.).

Germany and Austria as developed countries have sufficient information resources and are characterized by a high level of infrastructure development. Analysis of the innovation potential elements impact on GDP and export of goods and services in Germany and Austria revealed that the greatest impact on the national economy's competitiveness of developed EU countries is provided by scientific, financial and economic and human resources. For Austria, the significance of the effectiveness of innovation has been also revealed.

Generally, innovation potential plays an important role in providing the competitiveness of the Austria and Germany national economies in the global economy. At the same time, the innovation potential is not fully utilized. Among the reasons for this are economic, financial, social instability as a result of the 2008 global financial crisis, the EU debt crisis, migration processes. In addition, the human resource is not optimal. In this regard, countries need to correct the innovation policy aimed at strengthening the interconnection between the innovation potential elements. Austria should pay more attention to the integration of such elements as education, science, R\&D development and implementation. It is advisable for Germany to improve the innovation policy in the context of increasing efficiency and effectiveness of implementing the R\&D results in economic activity, as well as the creation and use of human resources.

\section{References:}

Akaev, A. A. (2013). Bolshie tsiklyi konyyunkturyi i innovatsionno-tsiklicheskaya teoriya ekonomicheskogo razvitiya Shumpetera-Kondrateva [Schumpeter-Kondratiev theory of innovation cyclical economic growth as a basis for the strategic management of sustainable development]. Ekonomicheskaya nauka sovremennoy Rossii Economics of Contemporary Russia, № 2(61). (in Russian)

Cornell INSEAD WIPO. (2017). The Global Innovation Index 2017: Innovation Feeding the World. Retrieved from: https://www.globalinnovationindex.org/gii-2017-report

Drucker, P.F. (1985). Business and innovation. New York: HarperCollins.

Heiets, V. M. \& Danylenko, A. I. \& Zhulynskyi, M. H. \& Levenets, Yu. A. \& Libanova, E. M., \& Onyshchenko, O. S. (2010). Novyi kurs: reformy v Ukraini. 2010-2015. Natsionalna dopovid [New Deal: reform in Ukraine. 2010-2015. National Report]. Kiyv: SIC Vernadsky National Library (in Ukrainian)

Kalcsú, Z. \& Magyar D. (2009). Regional Situation Analysis on the Innovation potential of the West - Transdanubian Region. Retrieved from: http:www.southeast-europe.net/document.cmt?id=113

Kornilov, D.A. \& Beliaev, O.G. (2012). Otsenka innovatsionnogo potentsiala regiona [Evaluation of innovation potential of the region]. Trudyi Nijegorodskogo gosudarstvennogo tehnicheskogo universiteta im. R.E. Alekseeva Transactions of Nizhny Novgorod State Technical University n.a. R.E. Alekseev, № 3(96). Retrieved from: http://www.nntu.ru/trudy/2012/03/254-261.pdf (in Russian)

Mazzucato, M., \& Perez, C. (2014). Innovation as Growth Policy: The Challenge for Europe. SPRU Working Paper Series SWPS, №13. Retrieved from: https://www.sussex.ac.uk/webteam/gateway/file.php?name=2014-13-swpsmazzucato-perez.pdf\&site $=25$

Nauwelaers, C. \& Reid, A. (2005). Methodologies for the evaluation of regional innovation potential. Scientometrics, Vol. 34, № 3, 497-511.

Österreichische Forschungsförderungsgesellschaft. (2017). Retrieved from: https://www.ffg.at 
The World Intellectual Property Organization. (2017). Global Innovation Index 2017: Switzerland, Sweden, Netherlands, USA, UK Top Annual Ranking. Retrieved from: http://www.wipo.int/pressroom/en/articles/2017/ article 0006.html\#about

The European Commission. (2017). Innovation. Retrieved from: http://ec.europa.eu/growth/industry/ innovation_en

The European Commission. (2012). Press Memo. Retrieved from: http://europa.eu/rapid/press-release_MEMO12-834_en.htm

The European Patent Office. (2017). Statistics. Retrieved from: http://www.epo.org/about-us/annual-reportsstatistics/statistics.html

The World Bank. (2017). World Development Indicators. Retrieved from: http://databank.worldbank.org/data/ reports.aspx?source=world-development-indicators

The World Economic Forum. (2017). The Global Competitiveness Report 2017-2018. Retrieved from: https://www.weforum.org/reports/the-global-competitiveness-report-2017-2018

Trade Representation of the Russian Federation in the Austrian Republic (2017). Overview of the economic situation and the main directions of foreign economic activity of Austria for 2016. Retrieved from: http://91.206.121.217/ TpApi/Upload/d72860c8-6594-430a-8c61-c736bb714918/obzor_economy_Austria_2016.pdf

Trade Representation of the Russian Federation in the Federal Republic of Germany (2017). Overview of the economic situation and the main directions of foreign economic activity of the Federal Republic of Germany for 2016. Retrieved from: http://91.206.121.217/TpApi/Upload/3119d445-1773-435f-a57e-a69cb190f456/Obzor_ economy_FRG_2016.pdf

UNESCO. (2017). Gross domestic expenditure on R\&D (GERD). Retrieved from: http://uis.unesco.org/indicator/ sti-rd-gerd-total 